\title{
Será o Escritor Funcionário Público um Bom Servidor?
}

\author{
ALMEIDA FISCHER \\ Presidente da Associação Nacional \\ de Escritores
}

O problema do escritor funcionário público - de resto semelhante ao do artista criador em geral - tem sido por vêzes focalizado em muitos de seus aspectos, sendo sempre assunto digno da atenção dos nossos estudiosos de questões administrativas. Será o escritor funcionário público, nos dias atuais, um bom servidor? Eu responderia que sim, de maneira geral. Há, no entanto, quem discorde dessa opinião, citando exemplos de escritores que, nas repartições públicas, saem durante o expediente, ocupam-se de tarefas particulares no horário de trabalho, usam máquina de escrever e papel do Estado na elaboração de seus escritos.

No passado os escritores funcionários públicos eram perfeitos burocratas, dedicados por inteiro ao serviço de suas repartiçôes. José Veríssimo, por exemplo, era funcionário exemplar, como Fiscal de Seguros da Secretaria da Fazenda, conforme nos afirma seu filho e biógrafo, Marechal Ignacio José Veríssimo: "havia sido o funcionário pontual, assiduo, honesto, o Fiscal intransigente, e o representante exato dos interêsse do Estado. Estava contente e sentia que êsse contentamento era justo" (1). Lima Barreto também foi, de início, bom funcionário, como amanuense da Secretaria da Guerra, segundo nos informa Francisco de Assis Barbosa: "Era pontual, ativo e cumpridor dos deveres. Tinha péssima letra, é verdade, mas isso não representava obstáculo irremovível ao exercício da carreira, que encetava sob tão bons auspícios. Como redigia com facilidade, davam-lhe para fazer minutas de avisos, portarias ou decretos" ${ }^{(2)}$.
Mais tarde, vencido pela bebida e pela doença, viera a tornar-se funcionário relapso (3). Artur Azevedo, funcionário da Secretaria da Agricultura, Indústria e Comércio durante trinta e três anos, tendo galgado todos os postos burocráticos, inclusive o de Diretor-Geral, no qual sucedeu a Machado de Assis, foí igualmente servidor público exemplar, de acôrdo com o que nos informa $R$. Magalhães Júnior, seu principal biógrafo: "era funcionário exemplaríssimo, metódico, organizado. Um processo não lhe saía das mãos sem ter sido cuidadosamente estudado e seus pareceres eram primores de clareza e concisão. Não encerrava um processo sem indicar, à margem, a data do Diário Oficial em que fôra publicado o despacho." (4). No mesmo livro, páginas adiante, Magalhães Júnior acrescenta: "Doente, com o velho médico a visitá-lo e a adverti-lo de que não devia sair à rua, que faz êsse burocrata incrível? Simplemente isto: pede que lhe mandem o trabalho em casa!" (5). Machado de Assis, seu amigo e colega de Secretaria, a que sucedeu no cargo de Diretor-Geral, após a aposentadoria do romancista de "Dom Casmurro", servidor do Estado durante quase a vida inteira, é apontado em numerosos estudos como excelente funcionário. Após os 35 anos ininterruptos de trabalho, aposentou-se em 1908, para vir a falecer pouco depois, no mesmo ano. José Maria Bello, um dos estudiosos de sua vida e de sua obra, dá-nos a informação: "Segundo o testemunho unânime dos que com êle conviveram no serviço administrativo, realizava o funcionário público ideal: probo, laborioso e disciplinado. O seu respeito pelas rígidas fórmulas e pela 
hierarquia burocrática era tão exagerado que parecia roçar pela humildade." (6). Eu poderia aumentar grandemente a relação, incluindo nela Olavo Bilac, Alberto de Oliveira, Mário de Andrade, Ribeiro Couto e muitíssimos outros expoentes de nossas letras, que foram servidores públicos exemplares.

Os escritores funcionários públicos do passado, quase sempre muito bons pontuais, assíduos e competentes -, eram em geral bem remunerados e podiam dedicar-se inteiramente às suas funções. Exceção feita inclusive a Lima Barreto, que percebia vencimentos muito baixos. Talvez por isso viesse a tornar-se funcionário faltoso, a miséria o levando, após alguns anos de bons serviços ao Estado, ao álcool e à neurastenia.

José Veríssimo, no entanto, ganhava, em 1909, um conto de réis, como Fiscal de Seguros da Secretaria da Fazenda. Machado de Assis sempre percebera vencimentos muito bons, como alto funcionário da Secretaria de Agricultura, Comércio e Obras Públicas. Artur Azevedo, também alto funcionário, na mesma época, ganhava bem, como substituto de Diretores-Gerais e sucessor de Machado de Assis nesse mesmo cargo, após sua aposentadoria. E, assim, todos os servidores exemplares. O que o Estado lhes pagava era, em geral, suficiente para que pudessem levar uma vida sem aperturas financeiras, garantindo sua própria subsistência e a da família com boas folgas. Nos jornais e revistas para os quais escreviam, faziam-no mais por diletantismo, para dar vazão aos seus impulsos criadores, vez que recebiam vales ridículos por seus trabalhos.

Acontece que, de muitos anos a esta parte, a remuneração dos funcionários públicos vem sofrendo imensos desgastes, os reajustamentos concedidos jamais correspondendo à elevação real do custo de vida. Em conseqüência, nem mesmo os servidores de nivel acima de 20 , que representam uma minoria, conseguem atender convenientemente às suas necessidades com o que ganham nas repartições a que servem. Isso leva os mais dotados - entre êles os escritores e artistas - a buscarem fora do Serviço Público a suplementação de orçamento doméstico de que necessitam. Então, já não são mais pontuais nem assíduos. Mas continuam eficientes e cumpridores dos seus deveres. Acontece, então, que alguns escritores funcionários saem durante o expediente, escrevem trabalhos para revistas e jornais no horário de trabalho, e usando máquina e papel pertencentes ao Estado. Uma reportagem, para revista grande e importante, representa para êles, muitas vêzes, alguns salários mensais.

Na hora, porém, em que seus chefes necessitam da elaboração de um trabatho de responsabilidade, uma exposição de motivos, um estudo mais sério, um anteprojeto de decreto ou de lei, com valor formal e de conteúdo, que nenhum manual de correspondência oficial ensina, chamam-nos e lhes dão a incumbência, que é imediatamente executada, com talento e proficiência. Um funcionário meramente burocrático, cumpridor de horários, levaria semanas para fazer o mesmo trabalho, e com erros de sintaxe, de semântica e outros que tais, além de vazio de fluência e comunicabilidade.

Conheço funcionários escritores, que são faltosos quanto à pontualidade e assiduidade, que dão às suas repartições uma produção infinitamente superior à dos seus colegas, de mesma carreira e categoria, que batem o ponto à hora certa, não faltam nunca ao trabalho, não lêem jornais e nem escrevem trabalhos para revistas e diários durante o expediente - e nem nunca, porque não têm capacidade para fazê-lo - , limitandose a permanecer bonzinhos em suas mesas, sem fazerem nada o dia inteiro, esforçando-se no sentido de darem a impressão de que estão ocupados com alguma coisa da mais alta transcendência. Os chefes louvam-lhes a exemplaridade mas, quando necessitam de alguém que execute trabalho de real importância, recorrem aos faltosos, mas competentes. Então, o que me parece fundamental é mudar o conceito sôbre o que seja funcionário exemplar. Eficiente é o servidor que produz mais, em quantidade e qualidade, e não o que gasta seu banco o dia inteiro, fazendo de conta que trabalha ao abrir e fechar gavetas. Lima Barreto já dizia que "sempre que você vir um sujeito qualquer abrindo e fechando gavetas, não tenha a menor dúvida, é que êle não tem nada o que fazer." (7).

O que o escritor funcionário talvez faça, durante o expediente, enquanto não há trabalho a executar - escrevendo artigos, contos, poemas ou indo até a editôra de que é diretor cultural ou de edições - interessa ao desenvolvimento cultural do país, à difusão de idéias e à 
fixação de fatos ou fastos nacionais. 0 que o burocrata faz, enquanto não há não the dão, se de alguma importântrabalho a executar - e quando o há

cia —, não interessa a ninguém. Nem a êle mesmo.

Serão os escritores funcionários bons servidores públicos? Eu diria que sim.

\section{N O T A S}

(1) "José Veríssimo Visto por Dentro" Ignacio José Veríssimo - Edições Govêrno do Estado do Amazonas - Manaus, 1966. pág. 76.

(2) "A Vida de Lima Barreto" - Francisco de Assis Barbosa - Livraria José Olympio Editôra - Rio, 1952, pág. 122.

(3) "O Conto da Vida Burocrática" - R. Magalhães Júnior - Editôra Civilizaçăo Brasileira - Rio, 1960, pág. 43.
(4) "Artur Azevedo e sua Epoca" - R. Magalhăes Júnior - Editôra Civilizaçăo Brasileira - Rio, 1966, pág. 56.

(5) Ibidem - pág. 63.

(6) "Retrato de Machado de Assis" - José Maria Bello - Editôra A Noite - Rio, s/d, pág. 91.

(7) "A Vida de Lima Barreto" - Francisco de Assis Barbosa - Editôra A Noite - Rio, págs. $123 / 124$. 